\title{
Carbon Sequestration Potential of Native Vegetation in Sivagangai District of Southern Tamil Nadu, India
}

\author{
A. Balasubramanian, C.N. Hari Prasath* and S. Radhakrishnan \\ Department of Silviculture, Forest College and Research Institute, Tamil Nadu Agricultural \\ University, Mettupalayam - 641 301, Tamil Nadu, India \\ *Corresponding author
}

\begin{tabular}{|c|c|}
\hline & A B S T R A C T \\
\hline Keywords & \multirow{4}{*}{$\begin{array}{l}\text { A field experiment was conducted to assess the carbon sequestration potential of } \\
\text { native vegetation in trees, shrubs and herbs at Nattarasankottai Village, Sivaganga } \\
\text { district in Tamil Nadu that lies between } \mathrm{N}^{\circ} 52^{\prime} 13.37^{\prime} \text { ' and E } 78^{\circ} 33^{\prime} 06.80^{\prime} \text { '. The } \\
\text { native vegetation was assessed for its carbon accumulation potential in five trees, nine } \\
\text { shrubs and six herbs. Among the five tree species, Acacia leucophloea exhibited } \\
\text { maximum biomass carbon content of } 532.32 \mathrm{~kg} \mathrm{ha}^{-1} \text { and minimum in Acacia mellifera } \\
\left(77.99 \mathrm{~kg} \mathrm{ha}^{-1}\right) \text {. Whereas in shrub species, Dodonaea viscosa recorded the highest } \\
\text { biomass carbon content of } 1391.42 \mathrm{~kg} \mathrm{ha}^{-1} \text { and lowest in } \text { Opuntia dellenii }(29.36 \mathrm{~kg} \\
\left.\mathrm{ha}^{-1}\right) \text {. In herbs, Sida cordifolia exhibited highest biomass carbon content }(262.09 \mathrm{~kg} \\
\left.\left.\mathrm{ha}^{-1}\right) \text { and the lowest in Ocimum basilicum ( } 41.24 \mathrm{~kg} \mathrm{ha} \mathrm{H}^{-1}\right) \text {. The field study inferred } \\
\text { that, Acacia leucophloea (Trees), Dodonaea viscosa (Shrubs) and Sida cordifolia } \\
\text { (Herbs) contributed maximum biomass carbon content to the native vegetation under } \\
\text { dry land condition. }\end{array}$} \\
\hline $\begin{array}{l}\text { Native } \\
\text { vegetation, } \\
\text { Wasteland, } \\
\text { Biomass carbon, } \\
\text { Trees, Herbs. }\end{array}$ & \\
\hline Article Info & \\
\hline $\begin{array}{l}\text { Accepted: } \\
23 \text { May } 2017 \\
\text { Available Online: } \\
\text { 10 June } 2017\end{array}$ & \\
\hline
\end{tabular}

\section{Introduction}

Climate change or global warming is largely dictated by carbon dioxide $\left(\mathrm{CO}_{2}\right)$. Rising concentration of greenhouse gases (GHGs) in the atmosphere could lead to a change in solar energy balance and consequently the world's climate. Among the anthropogenic GHGs, $\mathrm{CO}_{2}$ is the most abundant and responsible for half of the radioactive rays forcing associated with the greenhouse effect that leads to global warming (Reddy et al., 2010). In the wake of global efforts to address climate change, considerable interest has been generated about carbon sequestration potential of trees. Tree plantations are being considered as a mitigation option to reduce atmospheric $\mathrm{CO}_{2}$ and climate change (Kraenzel et al., 2003).
Terrestrial ecosystems play an important role in the global carbon cycle and hence it modify the atmospheric $\mathrm{CO}_{2}$ mixing ratio as they can act as carbon sink due to net carbon uptake during vegetation growth and carbon source through deforestation or forest degradation (Schulze, 2006). Forests in the tropics are particularly in focus due to the potential high plant productivity on one hand and a high level of deforestation and forest degradation on the other hand. Therefore, carbon sequestration in tropical forests adds as a positive way for carbon mitigation. Basically, three forestry actions that can increase carbon fixation relative to the baseline are adding forestland, lengthening rotations and 
increasing management intensity (Haile et al., 2008). The largest potential for carbon sequestration through trees is vested in subtropical and tropical regions. The biomass and carbon content estimation for each species as well as each native vegetation component is need to be documented (Lamlom and Savidge, 2003). Most studies, however, have focused on total aboveground biomass and carbon storage, whereas discrimination among the different parts of the tree, shrubs and herbs is rarely done.

On studying the above lacuna, the study was initiated to study the carbon sequestration potential of the trees, shrubs and herbs in the native vegetation. This could provide new information to improve the accuracy in the estimation of carbon content for assessing the contribution of species towards the increasing ecosystem service of carbon fixation and storage.

\section{Materials and Methods}

\section{Study area and planting material}

The study was conducted between 2014 2015 at Nattarasankottai Village, Sivaganga district in Tamil Nadu that lies between $\mathrm{N}$ 9 $52^{\prime} 13.37^{\prime \prime}$ and E 78 $33^{\prime} 06.80^{\prime \prime}$. The vegetation of the study area was shrubby grassland which was a typical wasteland lying fallow for decades together. The soil was red sandy clay type with the $\mathrm{pH}$ of 5.35-5.75 and electrical conductivity with $0.11 \mathrm{dS} \mathrm{m} \mathrm{m}^{-1}$. The soil nutrient status was very low in available nitrogen (157-185 $\left.\mathrm{kg} \mathrm{ha}^{-1}\right)$, medium in available phosphorus (25-27 $\left.\mathrm{kg} \mathrm{ha}^{-1}\right)$ and high in available potassium $\left(320-350 \mathrm{~kg} \mathrm{ha}^{-1}\right)$. The mean annual rainfall was $400-600 \mathrm{~mm}$ and the mean annual temperature was $35^{\circ} \mathrm{C}$ during winter and $42-45^{\circ} \mathrm{C}$ during summer. In native vegetation, five trees (Acacia leucophloea, Acacia mellifera, Azadirachta indica, Bauhinia racemosa and Morinda tinctoria), nine shrubs (Cassia auriculata, Chomelia asiatica, Cissus quadrangularis, Dodonaea viscosa, Flueggea leucopyrus, Murraya exotica, Opuntia dillenii, Phoenix pusila and Plectronia parvifolia) and six herbs (Abutilon indicum, Achyranthes aspera, Leucas aspera, Ocimum basilicum, Sida cordifolia and Sida acuta) were present.

\section{Biomass estimation of native vegetation}

The amount of biomass present in the native vegetation was estimated by destructive analysis. Five native tree species, nine shrub species and six herb species for each species were selected for biomass sampling. The biometrical parameters like height, basal diameter and root length of the uprooted plants and trees were recorded. Then, the uprooted plant samples were fractionated into leaves, branches, stem and roots. Fresh weights of all the fractionated tree components were recorded immediately after felling using appropriate spring scales. Representative sample $(500 \mathrm{~g})$ of stem, branches, leaves and root was immediately transferred to the laboratory in double sealed polythene bags. The collected samples were dried in a hot air oven at $80^{\circ} \mathrm{C}$ till constant weight was obtained. The oven dry weight of the whole sample was calculated as per Lasco et al., (2005).

\section{Carbon estimation in biomass of native vegetation}

The plant samples of various components viz., stem, branches, leaves and roots of the targeted trees species were collected separately, air dried and oven dried. Oven dried biomass samples were grounded in a willey mill and carbon concentration in different vegetation components were determined based on the ash per cent as determined by procedure given by Allen $e t$ al., (1986). Carbon per cent in above ground 
biomass (AGB), below ground biomass (BGB), litter and dead organic matter was estimated by using the formula given by Dey (2005) and Dhruw et al., (2009).

Carbon $\%=100 \%-\{$ Ash $\%+$ Molecular weight of $\mathrm{O}_{2}(53.3 \%)$ in $\mathrm{C}_{6} \mathrm{H}_{12} \mathrm{O}_{6}$ \}

The carbon stock in the above ground biomass, below ground biomass, litter and dead organic matter was computed by using the formula given below.

Carbon $(\mathrm{MT})=$ Biomass $(\mathrm{MT}) \times$ Carbon per cent

Percentage of organic carbon using the above procedure was estimated for all samples of fractionated biomass viz., leaf, stem, branch and root. Using the carbon per cent value, the above ground organic biomass carbon $\left(\mathrm{t} \mathrm{ha}^{-1}\right)$, below ground organic biomass carbon $\left(\mathrm{t} \mathrm{ha}^{-1}\right)$ and total organic biomass carbon $\left(\mathrm{t} \mathrm{ha}^{-1}\right)$ were calculated for individual species on per hectare basis.

The total biomass carbon was calculated by using the following formula.

i) AGB carbon $\left(\mathrm{t} \mathrm{C} \mathrm{ha}^{-1}\right)=$ Components of above ground biomass ( $\mathrm{t} \mathrm{ha}^{-1}$ ) $\mathrm{x}$ Carbon content $(\%)$

ii) BGB carbon $\left(\mathrm{t} \mathrm{C} \mathrm{ha}{ }^{-1}\right)=$ Components of below ground biomass $\left(\mathrm{t} \mathrm{ha}^{-1}\right) \mathrm{x}$ Carbon content $(\%)$

iii) Total biomass carbon stock $\left(\mathrm{t} \mathrm{C} \mathrm{ha}^{-1}\right)=$ AGB carbon + BGB carbon

\section{Statistical analysis}

The data obtained were subjected for statistical analysis to evaluate the possible relationship between the different parameters and analysis of variance employing statistical methods described by Panse and Sukhatme (1985).

\section{Results and Discussion}

Forest vegetation plays major role in global carbon cycle. It is evident that forest and its soils shares almost 60 per cent of the world's terrestrial carbon (Winjum et al., 1992). The concept of carbon sequestration emerged in eighties due to the consequences of steadily increasing level of carbon dioxide in the atmosphere. Accordingly, the present study was carried out to estimate carbon present in the biomass of existing native vegetation. In the study site, shrubby type of vegetation was present due to climatic, edaphic and biotic pressures prevailing in the area. In native trees, Acacia leucophloea results the highest carbon content of $125.05 \mathrm{~kg} \mathrm{ha}^{-1}, 251.04 \mathrm{~kg}$ $\mathrm{ha}^{-1}$ and $120.28 \mathrm{~kg} \mathrm{ha}^{-1}$ in branch, stem, and root respectively. It was eventually holding the highest total carbon content of $532.32 \mathrm{~kg}$ $\mathrm{ha}^{-1}$ followed by Azadirachta indica with its biomass carbon content of $369.01 \mathrm{~kg} \mathrm{ha}^{-1}$, this species also hold a maximum leaf biomass carbon content of $44.89 \mathrm{~kg} \mathrm{ha}^{-1}$. The lowest biomass carbon content of $77.99 \mathrm{~kg} \mathrm{ha}^{-1}$ was recorded in Acacia mellifera (Table 1).

The present study also revealed that carbon percentage was more in stem and root when compared to branch and leaf. Similar variation in carbon content was reported by Dhruw et al., (2009). The present result also help to conclude that when compare to leaf and branch and root, stem contributed more amount of carbon holding capacity in all vegetation types viz., tree, shrub, herbs and ground vegetation. Whereas in shrub species, Dodonaea viscosa recorded the highest biomass carbon content of $1391.42 \mathrm{~kg}$ ha $^{-1}$ followed by Flueggea leucopyrus (706.02 $\left.\mathrm{kg} \mathrm{ha}^{-1}\right)$, Plectronia parvifolia (566.20 $\mathrm{kg} \mathrm{ha}^{-1}$ ) and Cassia auriculata (487.85). The lowest biomass carbon content of $29.36 \mathrm{~kg} \mathrm{ha}^{-1}$ and 
$47.69 \mathrm{~kg} \mathrm{ha}^{-1}$ was registered in Opuntia dellenii and Cissus quadrangularis respectively (Table 2 ).

Negi et al., (2003) estimated the carbon allocation in different components of Indian trees and conclude that wood accumulated more carbon content when compare to leaf and bark in different genera of trees pertaining to conifers, deciduous, dicotyledons, evergreen dicotyledons, monocotyledon and exotic tree species. In herbs, Sida cordifolia exhibited highest biomass carbon content $\left(262.09 \mathrm{~kg} \mathrm{ha}^{-1}\right)$ and the lowest in Ocimum basilicum (41.24 $\mathrm{kg} \mathrm{ha}^{-1}$ ). The research result evidenced that the biomass carbon content was highest in shrubs followed by trees and herbs.

Table.1 Biomass carbon $\left(\mathrm{kg} \mathrm{ha}^{-1}\right)$ in native tree species

\begin{tabular}{clccccc}
\hline Sl.No & \multicolumn{1}{c}{ Treatment } & Leaf & Branch & Stem & Root & Total \\
\hline 1 & Acacia leucophloea & 35.95 & 125.05 & 251.04 & 120.28 & 532.32 \\
2 & Acacia mellifera & 7.62 & 18.34 & 31.87 & 20.16 & 77.99 \\
3 & Azadirachta indica & 44.89 & 87.31 & 156.52 & 80.29 & 369.01 \\
4 & Bauhinia racemosa & 29.89 & 48.51 & 127.39 & 54.68 & 260.47 \\
5 & Morinda tinctoria & 10.14 & 25.09 & 38.71 & 18.99 & 92.93 \\
\hline & SEd & 0.41 & 0.67 & 1.01 & 0.68 & 4.33 \\
& $\mathrm{CD}(0.05)$ & 0.90 & 1.47 & 2.20 & 1.50 & 9.44
\end{tabular}

Table.2 Biomass carbon $\left(\mathrm{kg} \mathrm{ha}^{-1}\right)$ in native shrub species

\begin{tabular}{clccccc}
\hline SI.No & \multicolumn{1}{c}{ Treatment } & Leaf & Branch & Stem & Root & Total \\
\hline 1 & Cassia auriculata & 53.18 & 134.14 & 181.35 & 119.18 & 487.85 \\
2 & Chomelia asiatica & 101.10 & 49.15 & 174.92 & 47.34 & 372.51 \\
3 & Cissus quadrangularis & 0.00 & 0.00 & 31.95 & 15.74 & 47.69 \\
4 & Dodonaea viscosa & 127.98 & 469.77 & 456.83 & 336.84 & 1391.42 \\
5 & Flueggea leucopyrus & 9.61 & 278.85 & 270.22 & 147.34 & 706.02 \\
6 & Murraya exotica & 35.63 & 55.56 & 102.38 & 52.36 & 245.93 \\
7 & Opuntia dillenii & 0.00 & 0.00 & 19.07 & 10.29 & 29.36 \\
8 & Phoenix pusila & 30.66 & 0.00 & 65.55 & 29.37 & 125.58 \\
9 & Plectronia parvifolia & 11.33 & 222.68 & 199.74 & 132.45 & 566.20 \\
\hline & SEd & 0.53 & 1.51 & 2.36 & 1.78 & 5.87 \\
& CD $(0.05)$ & 1.10 & 3.11 & 4.87 & 3.68 & 12.12
\end{tabular}

Table.3 Biomass carbon $\left(\mathrm{kg} \mathrm{ha}^{-1}\right)$ in native herb species 


\begin{tabular}{clcccc}
\hline Sl.No & \multicolumn{1}{c}{ Treatment } & Leaf & Stem & Root & Total \\
\hline 1 & Abutilon indicum & 16.85 & 128.33 & 44.01 & 189.19 \\
2 & Achyranthes aspera & 27.85 & 148.39 & 51.79 & 228.03 \\
3 & Leucas aspera & 30.00 & 57.84 & 34.57 & 122.41 \\
4 & Ocimum basilicum & 4.06 & 25.51 & 11.67 & 41.24 \\
5 & Sida cordifolia & 41.72 & 160.89 & 59.48 & 262.09 \\
6 & Sida acuta & 15.52 & 53.28 & 19.79 & 88.59
\end{tabular}

$\begin{array}{lllll}\text { SEd } & 0.68 & 1.46 & 0.85 & 2.91 \\ \mathrm{CD}(0.05) & 1.46 & 3.12 & 1.83 & 6.20\end{array}$

Though the carbon content percentage is more in trees when compared to shrubs and herbs, the amount of biomass carbon hold by shrubs was the highest when compare to all other vegetational components present in study site. Similar result was observed in Costa Rica by Brene and Montagnini (2006), on their study on carbon content of native plantations; they observed that high abundant and high biomass trees contributed more carbon than the less dense and less biomass tree species (Table 3).

In conclusion, the result of this study inferred maximum biomass carbon in Acacia leucophloea (Trees), Dodonaea viscosa (Shrubs) and Sida cordifolia (Herbs) under dry land condition. It is also evidenced that total biomass carbon content was highest in shrubs followed by trees and herbs in native vegetation.

\section{Acknowledgement}

The authors acknowledge the support of National Programme on Carbon Sequestration under the research project "Afforestation and Evaluation of few fast growing tree species for high carbon dioxide sequestration potential" funded by Department of Science and Technology (DST), Government of India implemented by Forest College and Research Institute, Mettupalayam with the association of Energy Plantation Projects India Public. Ltd. (EPPI), Sivgangai.

\section{References}

Allen, S.E., H.M. Grimshaw and A.P. Rowland. 1986. Chemical analysis. In: P.D. Moore and S.B. Champan (Eds.). Methods in Plant Ecology. Blackwell Scientific Publications. 285-344 pp.

Brene, A.R. and F. Montagnini. 2006. Growth, productivity, aboveground biomass, and carbon sequestration of pure and mixed native tree plantations in the Caribbean lowlands of Costa Rica. Forest Ecology and Management, 232: 168-178.

Dey, S.K. 2005. A Preliminary estimation of carbon stock sequestrated through Rubber (Hevea brasiliensis) plantation in North Eastern region of India. Indian Forester, 11: 1429-1436.

Dhruw, S.K., L. Singh and A.K. Singh. 2009. Storage and sequestration of carbon by leguminous and non-leguminous trees on red-lateritic soil of Chhattisgarh. Indian Forester, 135(4): 531-538.

Haile, S. G., P.K.R. Nair and V.D Nair.2008. Carbon storage of different soil-size fractions in Florida silvopastoral systems. J. Environ. Qual., 37: 17891797.

Kraenzel M A, Castillo T, Moore and Potvin C. 2003. Carbon storage of harvest-age teak (Tectona grandis) plantations, Panama. Forest Ecology and 
Management, 173: 213-225.

Lamlom, S.H. and R.A. Savidge. 2003. A reassessment of carbon content in wood: Variation within and between 41 North American species. Biomass Bioenergy, 25: 381-388.

Lasco, R.D., F.B. Pulhin, R.V.O. Cruz, J.M Pulhin and S.S.N. Roy. 2005. Carbon budgets of terrestrial ecosystems in the Pantabangan- Carranglan Watershed. In: Assessments of Impacts and Adaptations to Climate Change (AIACC) Working Paper. www.aiaccproject.org.

Negi, J.D.S., R.K. Manhas and P.S. Chauhan. 2003. Carbon allocation in different components of some tree species of India: a new approach for carbon estimation. Current Science, 85(11):
1528-1531.

Panse, V.G. and P.V. Sukhatme. 1985. Statistical methods for agricultural workers ( $4^{\text {th }}$ edn.). ICAR, New Delhi. $347 \mathrm{p}$.

Reddy, R., K.R. Girish Kasineni and Agepati S.Raghavendra. 2010. The impact of global elevated $\mathrm{CO}_{2}$ concentration on photosynthesis and plant productivity. Current Science, 99(1): 46-47.

Schulze, E.D., 2006. Biological control of the terrestrial carbon sink. Biogeosciences, 3: 147-166.

Winjum, J.K., R.K. Dixon and Schroeder. 1992. Estimating the global potential of forest and agroforestry management practices to sequester carbon. Water Air Soil Pollutes, 64(1-2): 213-227.

\section{How to cite this article:}

Balasubramanian, A., C.N. Hari Prasath and Radhakrishnan, S. 2017. Carbon Sequestration Potential of Native Vegetation in Sivagangai District of Southern Tamil Nadu, India. Int.J.Curr.Microbiol.App.Sci. 6(5): 1880-1885. doi: https://doi.org/10.20546/ijcmas.2017.606.219 